\title{
Teknik Kompresi pada Transmisi Data Citra Payload KOMURINDO
}

\section{Compression Technique on KOMURINDO Payload Image Data Transmission}

\author{
A Sanjaya ${ }^{1}$, M Aria $^{2 *}$ \\ 1)Program Studi Sistem Komputer, Fakultas Teknik dan Ilmu Komputer, Universitas Komputer Indonesia \\ Jl. Dipati Ukur No. 112 - 116, Bandung, Indonesia 40132 \\ 2)Program Studi Teknik Elektro, Fakultas Teknik dan Ilmu Komputer, Universitas Komputer Indonesia \\ Jl. Dipati Ukur No. 112 - 116, Bandung, Indonesia 40132 \\ *email:muhammad.aria@email.unikom.ac.id
}

\begin{abstract}
In the field of information technology, the image is an important element of the provision of visual information. As part of the KOMURINDO competition, the transmission of mage data and sensor data is a mandatory evaluation. Each data of acclerometer and gyroscope is sent one row in a row which is preceded by the header code. Payload will capture images mapped to $100 \times 100$ pixels, in 8-bit RGB bitmap format, uncompressed and sent via $433 \mathrm{MHz} 3 \mathrm{DR}$ radio waves. The $3 \mathrm{DR}$ radio can communicate $\pm 600 \mathrm{~m}$ with unhindered conditions. The bitmap image is a factor where the data sent to the recipient's computer takes $\pm 17,20$ seconds. This delay is long enough to retrieval and transmit a data image for the KOMURINDO 2017 case study. From these issues, the Huffman algorithm will be applied to compress image data so that it is smaller. The average time for send image data to be shorter is 5,55 seconds for images of $100 \times 100$ pixels.
\end{abstract}

Keywords - Image, Payload, Compression, Huffman, Bitmap, JPEG

\begin{abstract}
ABSTRAK - Dalam bidang teknologi informasi, citra merupakan elemen penting dalam penyediaan informasi visual. Pada kompetisi KOMURINDO, pengiriman data gambar dan data sensor merupakan penilaian wajib. Setiap data acclerometer dan gyroscope dikirim dalam satu baris secara berurut yang diawalai oleh header code. Payload akan menamngkap gambar yang dipetakan menjadi $100 \times 100$ pixel, dalam format bitmap RGB 8-bit, tanpa kompresi dan dikirim melalui gelombang radio $3 D R \quad 433 \mathrm{MHz}$. Radio $3 D \mathrm{D}$ dapat berkomunikasi $\pm 600 \mathrm{~m}$ dalam kondisi tanpa hambatan. Gambar bitmap yang dikirimkan ke computer menghabiskan waktu $\pm 17,20$ detik. Waktu tersebut terbilang lama untuk pengambilan dan pengiriman satu buah data citra untuk studi kasus KOMURINDO 2017. Dari permasalahan tersebut dalam penelitian ini akan diterapkan algoritma Huffman untuk melakukan pengkompresian data citra menjadi lebih kecil dan data citra yang dikompresi akan diubah ke format JPEG, dengan menggunakan metode huffman rata - rata waktu yang pengiriman data citra menjadi lebih pendek yaitu 5,55 detik untuk gambar beriukuran $100 \times 100$ pixel.
\end{abstract}

Kata Kunci - Citra, Payload, Kompresi, Huffman, Bitmap, JPEG

\section{Pendahuluan}

Dalam bidang teknologi informasi, citra merupakan elemen penting dalam penyediaan informasi visual. Saat bertukar data gambar, biasanya dilakukan dengan melakukan pengiriman data melalui media transmisi elektronik atau melalui gelombang radio dari satu komputer ke komputer yang lain. Ukuran data yang besar terkadang menjadi masalah selama proses pengiriman data.
Ukuran data yang besar mungkin membutuhkan waktu lebih lama dibandingkan dengan pengiriman data berukuran kecil. Selain itu, transmisi data ada resiko data yang ditransfer tidak dapat tersampaikan ke terminal komputer penerima[1]. Oleh karena itu, salah satu cara untuk menyelesaikan masalah ini adalah dengan menggunakan kompresi data.

Kompresi adalah proses mengubah sekumpulan data menjadi bentuk kode yang mengurangi 
kebutuhan penyimpanan dan mengurangi waktu pertukaran data[2]. Ada dua cara yang digunakan untuk kompresi data yaitu kompresi dan dekompresi. Kompresi adalah proses mengubah data string menjadi string yang memiliki informasi data yang sama dengan panjang bit yang lebih pendek. Salah satu metode kompresi gambar adalah metode huffman.

Pengiriman data gambar pada payload (muatan roket) KOMURINDO 2017 saat ini masih berukuran besar dan tidak terkompresi. Data gambar RGB yang berformat bitmap adalah salah satu faktor dimana data yang dikirimkan ke terminal (station) komputer penerima membutuhkan waktu \pm 20 detik. Waktu tersebut cukup lama untuk pengambilan data gambar dengan ukuran 100x100 pixel untuk studi kasus payload KOMURINDO 2017.

Dari permasalahan ini, dalam penelitian ini akan dikembangkan suatu algoritma yang melakukan pengkompresian data citra menjadi lebih kecil dengan menggunakan metode Huffman dan data citra yang dikompresi akan diubah ke dalam format JPEG. Dengan demikian, pengiriman data gambar ke terminal (station) penerima menjadi lebih cepat dan lebih efisien.

\section{METODE DAN BAHAN}

\subsection{Kompresi}

Kompresi merupakan proses mengkodekan informasi menggunakan bit atau information-bearing unit yang lain yang lebih rendah dari pada representasi data yang tidak terkodekan dengan suatu sistem enkoding tertentu. Pihak pengirim harus menggunakan algoritma kompresi data yang sudah baku dan pihak penerima juga harus menggunakan teknik dekompresi data yang sama dengan pengirim, sehingga data yang diterima dapat dibaca/di-dekode kembali dengan benar. Kompresi data menjadi sangat penting karena memperkecil kebutuhan penyimpanan data, mempercepat pengiriman data, dan memperkecil kebutuhan bandwidth. Teknik kompresi bisa dilakukan terhadap data teks/biner, gambar (JPEG, PNG, TIFF), audio (MP3, AAC, RMA, WMA), dan video (MPEG, H261, H263)[3]. Berdasarkan keluaran (output) dari hasil kompresi, hasil kompresi citra dapat diklasifikasikan ke dalam 2 (dua) bagian yaitu seperti ditunjukkan pada Gambar 1.
LOSSLESS
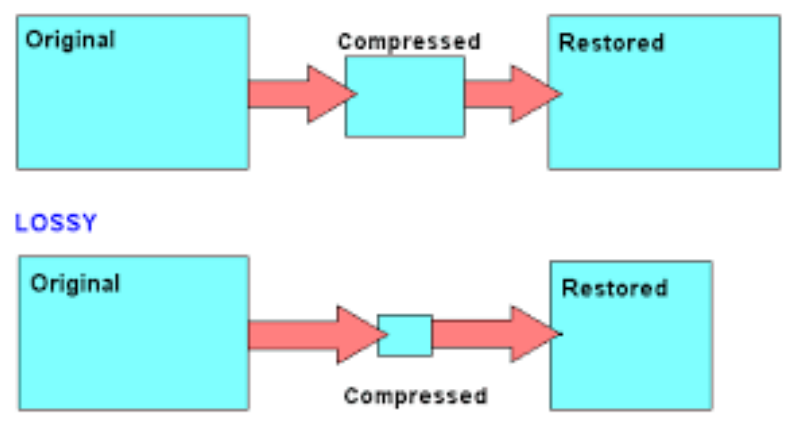

Gambar 1. Teknik Kompresi

Teknik lossless adalah sebuah teknik kompresi dan dekompresi yang keluarannya menghasilkan data citra dengan hasil kompresiannya sama dengan data citra asli. Teknik ini sangat membantu dalam kompresi citra yang mengandung informasi penting dan data citra tersebut tidak boleh rusak atau berubah kualitasnya akibat dari pengkompresian. Teknik kompresi citra seperti ini dilakukan dengan mengaplikasikan metode Huffman dengan cara melakukan pendekatan statistik dimana nilai warna yang frekuensi kemunculannya sering muncul dalam citra akan dikodekan dengan jumlah bit yang lebih sedikit atau pendek, sedangkan nilai warna yang frekuensi kemunculannya sedikit akan dikodekan dengan jumah bit yang lebih panjang. Dengan demikian, menggunakan teknik lossless compression ini tidak akan mengurangi atau merubah kualitas dari citra yang telah dilakukan proses kompresi.

Teknik lossy adalah suatu teknik kompresi yang dilakukan dengan meminimalkan jumlah bit pada informasi detail dari gelap terangnya suatu citra (luminance) dan informasi warna citra (chrominance). Teknik kompresi citra seperti ini dapat memperkecil jumlah bit yang dibutuhkan untuk pengkodean data citra. Kualitas citra yang dihasilkan menggunakan teknik ini akan sangat bergantung pada seberapa besar pengurangan nilai dari informasi detail citra. Semakin besar nilai detail data citra yang berkurang, maka semakin rendah kualitas data citra yang dihasilkan[4]. Teknik kompresi seperti ini akan menghasilkan ratio pengkompresian yang tinggi dibandingkan dengan metode lossless. Pada Gambar 2 adalah sebuah citra yang sebelum dikompresi, dan Gambar 3 merupakan hasil dari pengkompresain citra kapal dengan metode lossy. 


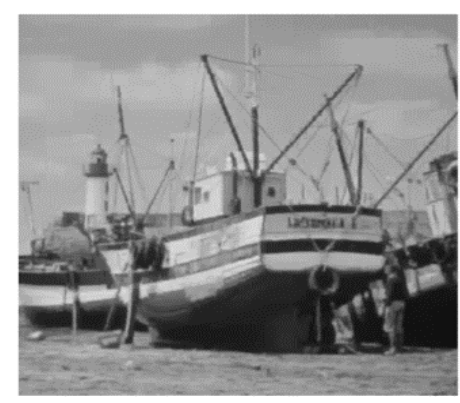

Gambar 2. Citra kapal sebelum dikompresi

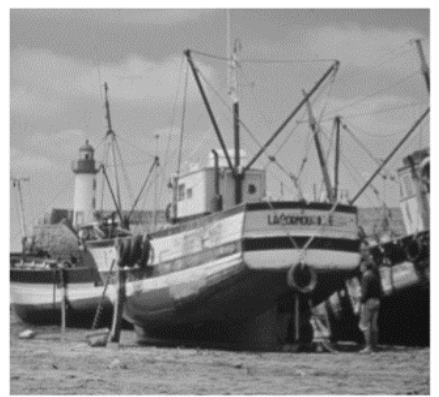

Gambar 3 Citra kapal sesudah dikompresi

\subsection{Metode Kompresi}

Metode kompresi merupakan pengkompresian data citra yang menggunakan beberapa algoritma kompresi seperti algortima LZW, DMC, dan Huffman. algortima tersebut termasuk kedalam algoritma pengkompresian data citra lossless yang dimana hasil dari pengkompresian tidak menghilangkan informasi warna pada sebuah citra yang akan dikompresi. Gambar 4 dan Gambar 5 menunjukkan perbandingan kecepatan dan rasio kompresi dari 3 algoritma diatas yang diambil pada salah satu jurnal penelitian [7].

Dari data grafik yang diambil dari [7] menjelaskan, hasil kompresi huffman lebih baik dibandingkan menggunakan metode LZW hanya pada kasus file biner, file multimedia, file gambar dan file hasil kompresi sehingga penulis memilih metode huffman untuk pengkompresian data citra untuk studi kasus payload KOMURINDO 2017.

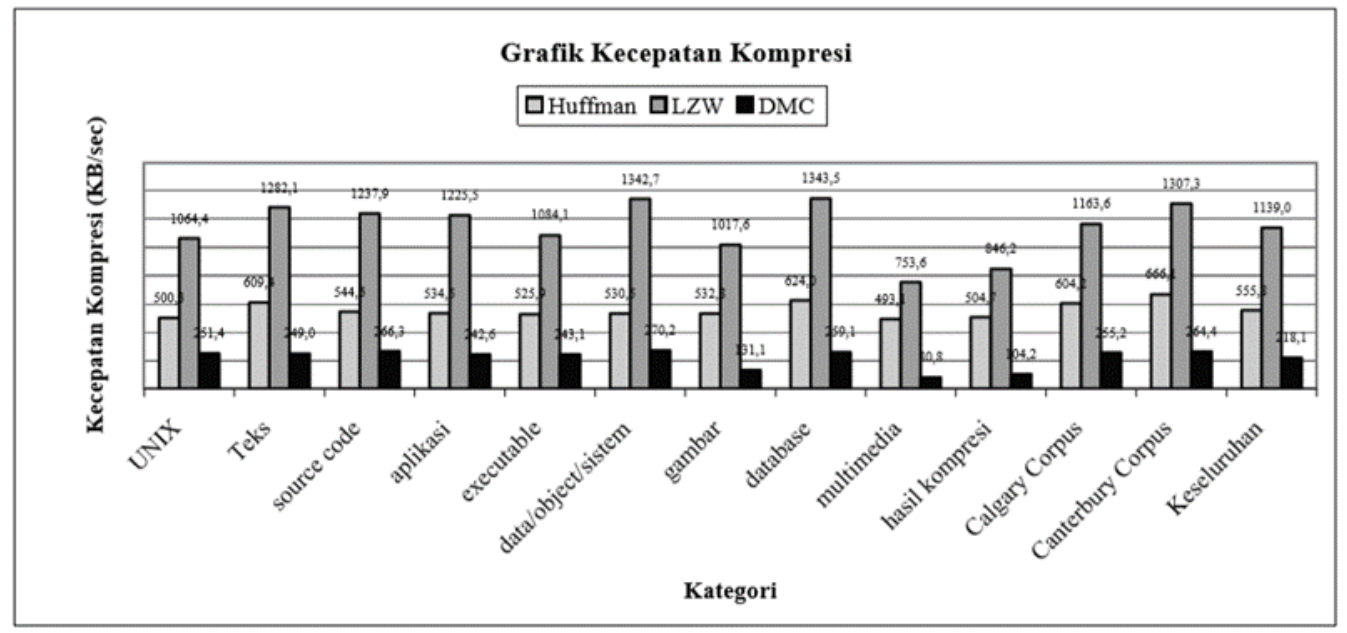

Gambar 4. Grafik perbandingan kecepatan kompresi pada beberapa type file

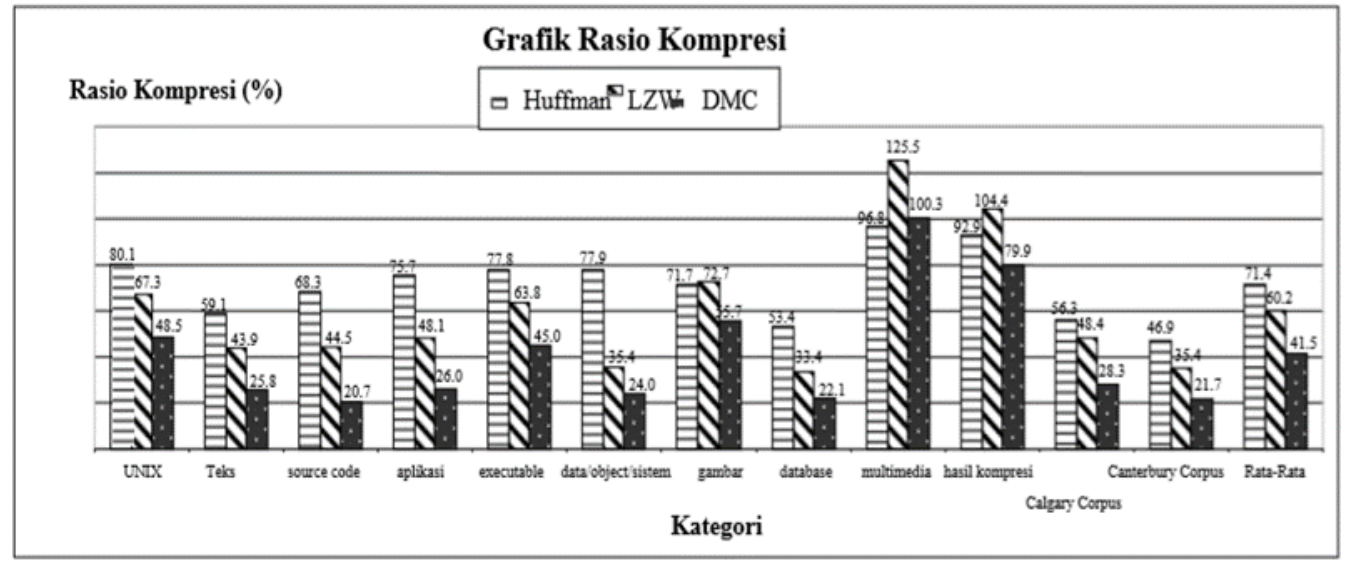

Gambar 5. Grafik perbandingan kecepatan kompresi pada beberapa type file 


\subsection{Metode Huffman}

Metode Huffman ditemukan oleh seorang professor MIT (Massachusets Instuate of Technology) yang bernama David Huffman pada tahun 1952. Metode Huffman ini termasuk kedalam kelompok kompresi lossless yang dimana tidak mengubah atau menghilangkan informasi dari data citra aslinya setelah dilakukan kompresi. Kode Huffman menggunakan prinsip pengkodean yang mirip dengan kode Morse, yaitu setiap karakter (simbol) dikodekan dengan rangkaian beberapa bit, setiap karakter yang sering muncul akan dikodekan dengan rangkaian bit yang pendek dan karakter yang jarang muncul dikodekan dengan rangkaian bit yang lebih panjang[5].

Citra yang telah dikompresi tentunya harus didekompresi agar citra tersebut sesuai dengan citra aslinya. Ada 2 (dua) cara yang dapat dilakukan dalam kompresi citra menggunakan metode Huffman, yaitu menggunakan binary tree dan tabel huffman[6]:

1. Menggunakan pohon huffman (binary tree) Langkah-langkah penguraian kode Huffman menggunakan pohon biner (binary tree) adalah sebagai berikut:

a) Membaca bit pertama dari data string biner.

b) Melakukan traversal pada pohon Huffman mulai dari akar (root) sesuai dengan bit yang dibaca.

c) Jika bit yang dibaca adalah nol "0" maka akar (root) yang dibaca adalah akar kiri, sementara itu jika bit yang dibaca adalah satu "1" maka yang dibaca adalah akar (root) kanan.

d) Jika anak dari pohon (tree) bukan daun maka baca bit berikutnya dari string biner.

Pada daun tersebut ditemukan symbol dan proses penguraian kode Huffman selesai.

2. Menggunakan tabel kode huffman.

Tabel kode Huffman disusun menggunakan prefix code, sehingga kode untuk sebuah karakter tidak boleh dan tidak bisa menjadi awalan dari kode yang lain. String biner yang dienkripsi dapat dipisahkan berdasarkan rangkaian bitnya untuk kemudian diuraikan menjadi sebuah data awal. Pada tahap penguraian kode ini digunakan tabel kode Huffman yang dapat melihat setiap rangkaian bit yang ditemukan dalam data string biner dan hasil enkripsi data didalam table kode Huffman. dibawah ini merupakan algoritma Huffman dalam proses mengkompresi data[4].

1. Input: $A=\{a 1, a 2, \ldots, a n\}$, merupakan symbol dari ukuran $n . W=\{w 1, w 2, \ldots, w n\}$, nerupakan symbol berat, $\mathrm{w} 1=$ weight(ai), $1 \leq \mathrm{i} \leq \mathrm{n}$.
2. Output: kode $\mathrm{C}(\mathrm{A}, \mathrm{W})=(\mathrm{c} 1, \mathrm{c} 2, \ldots, \mathrm{cn})$, merupakan panjang tuple dari kode biner, dimana ci merupakan kata kode untuk ai, $1 \leq$ $\mathrm{i} \leq \mathrm{n}$.

3. Goal : $\mathrm{L}(\mathrm{C})=$, merupakan berat panjangnya kata kode $\mathrm{C} . \mathrm{L}(\mathrm{C}) \leq \mathrm{L}(\mathrm{T})$ untuk setiap kode $\mathrm{T}(\mathrm{A}, \mathrm{w})$.

\section{HASIL DAN PEMBAHASAN}

Bagian ini membahas desain sistem yang akan dirancang untuk memenuhi maksud dan tujuan penelitian ini, yaitu mengirim data gambar menggunakan teknik kompresi, pemrograman android, pemrograman ground station, penampilan data sensor, kompresi gambar menggunakan metode Huffman. Sistem lengkap yang dibangun dapat dilihat pada Gambar 6. Berikut ini adalah penjelasan dari diagram blok untuk Gambar 6 .

1. Gambar adalah objek atau sebuah citra asli yang akan ditangkap oleh kamera ponsel.

2. Kamera menggunakan kamera yang terpasang pada ponsel Nexus 5 yang berfungsi untuk membuat atau menangkap gambar dari suatu objek, lalu kemudian direkam dan disimpam dalam format digital. Kamera pada ponsel Nexus 5 ini memiliki sensor f2.0 yang menangkap cahaya secara efisien.

3. Capturing, akan mendapatkan perintah dari GCS untuk mengambil citra.

4. Kompersi citra, berfungsi untuk mengkompres data citra bitmap yang ditangkap oleh kamera, dengan menggunakan metode Huffman dimana akan mengganti data citra dengan kode bit melalui pohon biner.

5. Sensor Accelerometer, Gyroscope, dan Orientation menggunakan sensor yang terdapat pada ponsel Nexus 5.

6. Bluetooth HC-06 yang dapat digunakan pada ponsel adalah untuk meneruskan komunikasi serial dari ponsel ke modul radio 3DR 433MHz.

7. Radio 3DR $433 \mathrm{MHz}$ menggunakan perangkat komunikasi RCTimer yang meneruskan data serial dari ponsel melalui bluetooth HC-06 untuk dikirimkan langsnung air-to-air ke Ground Control Station yang kemudian ditampilkan pada laptop.

8. Radio 3DR 433MHz yang tersedia di GCS sebagai radio receiver (penerima) dari komunikai radio yang ada pada payload.

9. Dekompresi citra, metode atau algoritma untuk mengembalikan data hasil kompresi menjadi data semula yang dikirimkan dari payload ke GCS. 


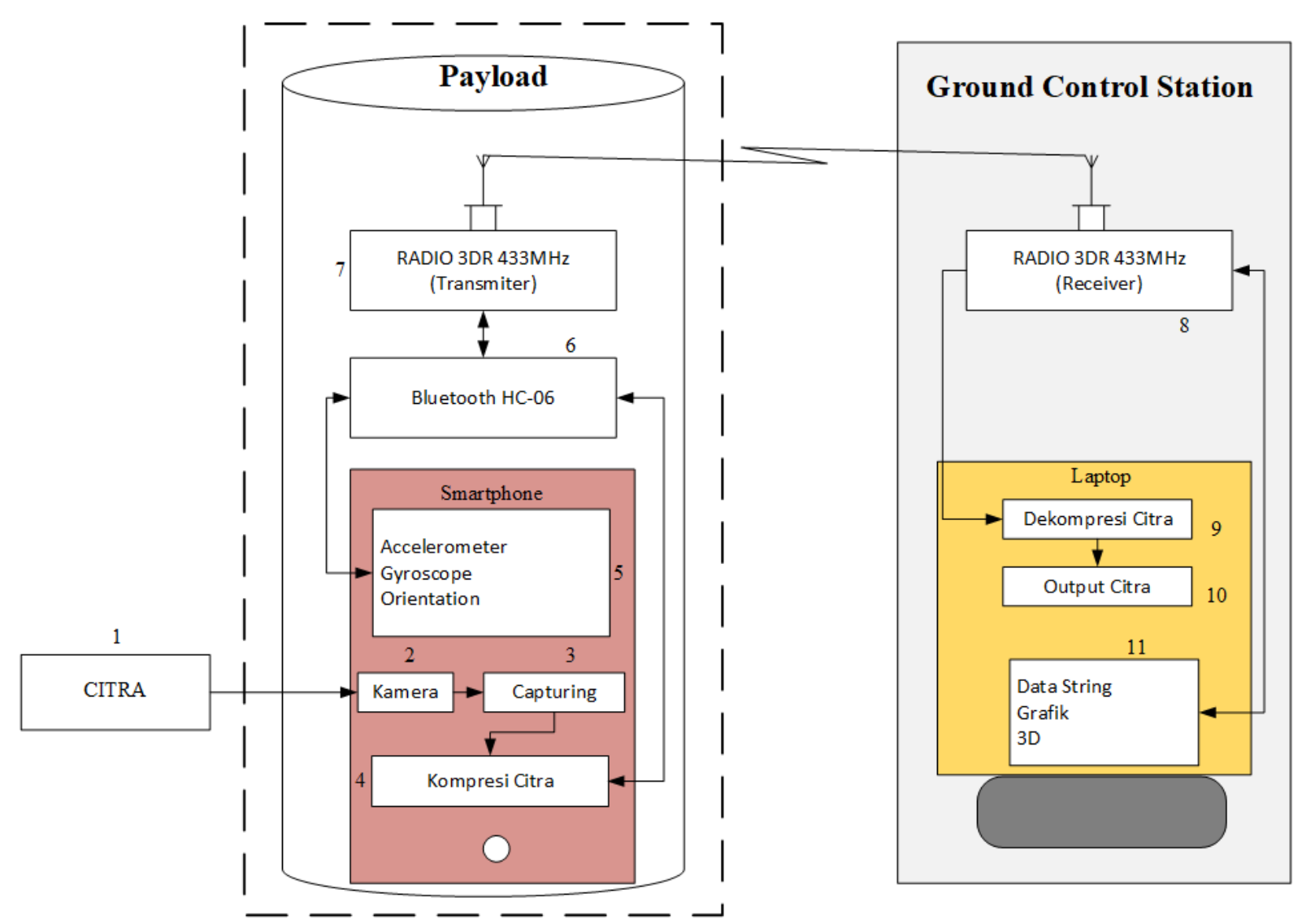

Gambar 6. Diagram blok sistem

10. Output citra untuk menampilkan hasil pengiriman data citra yang diterima dari payload yang telah didekompresi pada laptop GCS.

11. Dalam blok ini merupakan perangkat yang berisi Ground Control Station yang berfungsi untuk mengaktifkan telemetri serta berfungsi menampilkan data Accelerometer, Gyroscope, dan Orientation maupun data gambar pada control station.

Bagian diagram alir dari android untuk pengiriman data gambar ditunjukkan pada Gambar 7.

Penjelasan dari diagram alir pada Gambar 7 adalah sebagai berikut.

1. Frame kamera untuk pengambilan citra akan dibuat dan kamera ponsel akan difokuskan pada suatu objek.

2. Lensa kamera mencari fokus selama 2 detik.

3. Capturing data citra dan masukkan nilai data gambar RGB kedalam matriks.

4. Kirim inisialisasi dari data gambar yang dikirimkan pada GCS.

5. Konversi data matriks ke format gambar.

6. Menghitung probabilitas kemunculan dalam data gambar, lalu menyusun setiap jenis karakter dengan urutan karakter yang memilki jumlah paling sedikit ke jumlah yang paling banyak berdasarkan metode huffman.

7. Membuat pohon biner berdasarkan urutan karakter dari yang terkecil hingga yang terbesar.

8. Menghitung jumlah bit gambar yang sudah dikompres dengan pohon biner berdasarkan pada metode huffman.

9. Mengirimkan data gambar yang dikompresi pada GCS melalui radio.

Adapun bagian diagram alir dari GCS untuk penerimaan data gambar ditunjukkan pada Gambar 8.

Penjelasan dari diagram lair pada Gambar 8 adalah sebagai berikut.

1. Apakah tombol kompres tertekan? Jika ya, lanjutkan ke indeks 2 dan jika tidak lanjut ke indeks 7.

2. Mengirim perintah '\#3' ke payload untuk pengiriman data gambar terkompresi.

3. Mengidentifikasi bit gambar yang dikirim berupa kode Huffman.

4. Memasukan bit pada akar pohon.

5. Membangun kembali gambar ke data semula.

6. Tampilkan data citra yang terkompresi. 


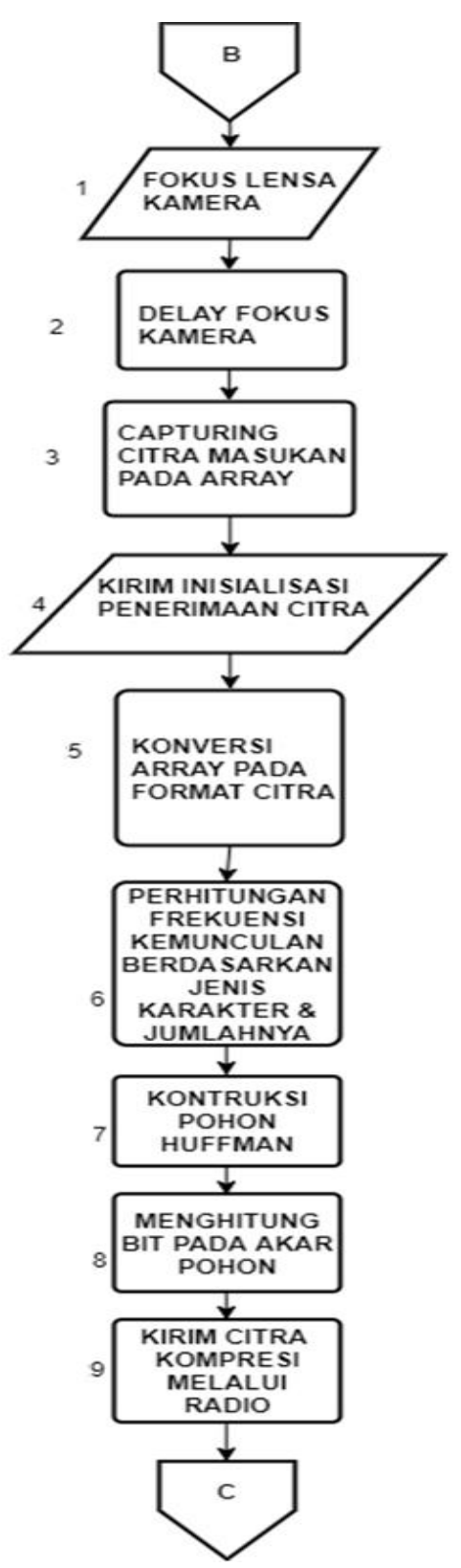

Gambar 7. Bagain diagram alir pengiriman gambar

\section{HASIl DAN PEMBaHASAN}

Untuk pengiriman data gambar dalam penelitian ini dibagi menjadi 2 bagian, yaitu pengiriman data gambar asli tanpa melalui teknik kompresi dan pengiriman data gambar setelah melalui teknik kompresi menggunakan metode huffman. Setiap jenis pengiriman menggunakan kode inisialisasi pengiriman yang sama namun berbeda untuk citra kompresi data RGB dikodekan terlebih dahulu menggunakan metode Huffman, sebelum ditransfer ke GCS oleh gelombang radio.

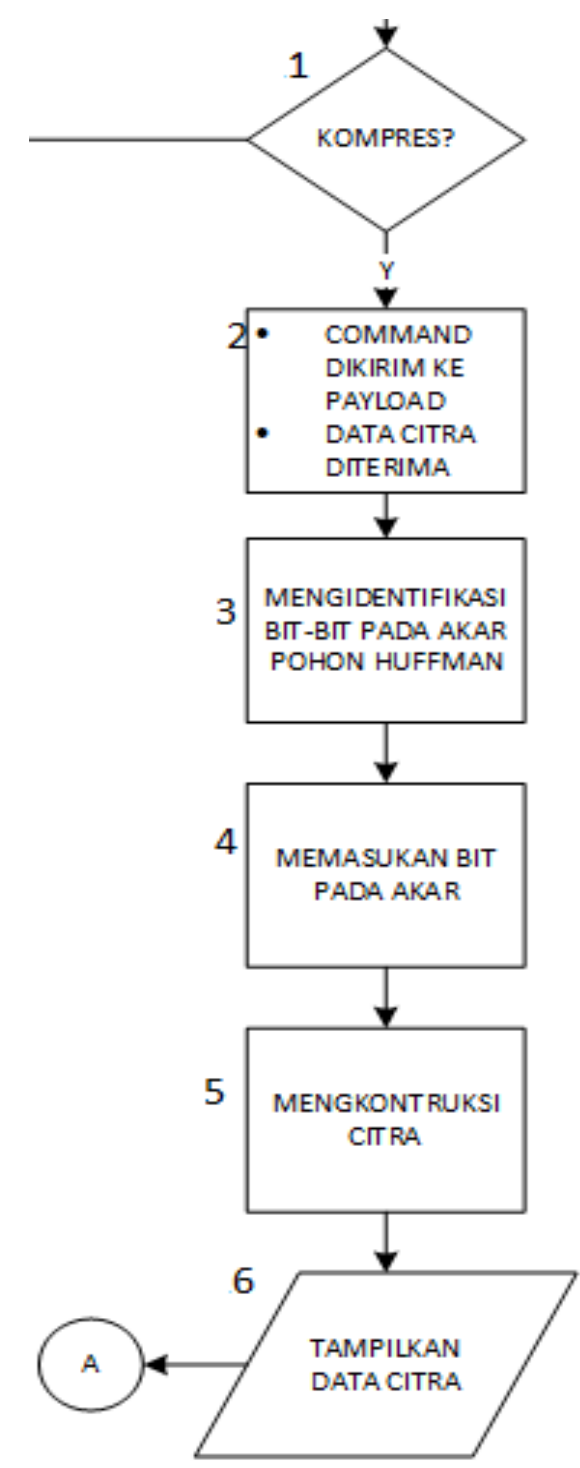

Gambar 8. Bagian diagram alir penerimaan gambar

\subsection{Pengujian Komunikasi Modul Radio Telemetri 3DR 433MHz}

Tes komunikasi radio dilakukan di lapangan terbuka di Lapangan Batununggal Bandung untuk membuktikan jangkauan pancar dari radio Telemetri yang digunakan. Pengujian komunikasi ini dilakukan pada kondisi daerah yang agak berpohon. Untuk mendapatkan jarak dari jangkauan radio Telemetri, maka percobaan dilakukan dengan mengirimkan data string header code " 008 " dengan data sensor dari payload ke Ground Station. Hasil pengujian ditunjukkan pada Tabel 1. 
Tabel 1. Pengujian jarak pancar radio telemetri

\begin{tabular}{|c|c|c|}
\hline $\begin{array}{c}\text { Jarak } \\
(\mathbf{m})\end{array}$ & $\begin{array}{c}\text { Kondisi (Tanpa } \\
\text { Penghalang) }\end{array}$ & $\begin{array}{c}\text { Kondisi } \\
\text { (Penghalang) }\end{array}$ \\
\hline 50 & $\begin{array}{c}\text { Berhasil (data } \\
\text { terkirim) }\end{array}$ & $\begin{array}{c}\text { Berhasil (data } \\
\text { terkirim) }\end{array}$ \\
\hline 100 & $\begin{array}{c}\text { Berhasil (data } \\
\text { terkirim) }\end{array}$ & $\begin{array}{c}\text { Berhasil (data } \\
\text { terkirim) }\end{array}$ \\
\hline 200 & $\begin{array}{c}\text { Berhasil (data } \\
\text { terkirim) } \\
\text { terkirim) }\end{array}$ \\
\hline 300 & $\begin{array}{c}\text { Berhasil (data } \\
\text { terkirim) }\end{array}$ & Berhasil (data \\
terkirim)
\end{tabular}

\subsection{Pengiriman Data Citra tanpa Teknik Kompresi}

Pada gambar ini, gambar yang dikirim dari payload ke GCS dengan resolusi 100x100 pixel tanpa melalui teknik kompresi masih memilki ukuran citra yang besar. Percobaan untuk pengambilan data citra dilakukan pada Lab. PLC dengan beberapa objek pengambilan yang berbeda. Pengiriman data citra RGB tanpa melalui teknik kompresi ini menghasilkan waktu lebih lama seperti dilihat pada Tabel 2.

Berdasarkan hasil pengujian pada Tabel 2 didapatkan gambar yang dikirim tanpa menggunakan teknik kompresi dan berformat bitmap menghasilkan waktu pengiriman rata-rata sebesar 17,20 detik dengan resolusi citra sebesar $100 \times 100$ pixel.
Tabel 2. Waktu pengiriman data gambar tanpa kompresi

\begin{tabular}{|c|c|c|c|}
\hline Objek & $\begin{array}{c}\text { Ukuran } \\
\text { File (Byte) }\end{array}$ & Dimensi & $\begin{array}{c}\text { Waktu } \\
\text { (detik) }\end{array}$ \\
\hline & 30.900 & $100 \times 100$ & 15,62 \\
\hline & 30.900 & $100 \times 100$ & 15,95 \\
\hline & 30.900 & $100 \times 100$ & 17,33 \\
\hline & 30.900 & $100 \times 100$ & 16,62 \\
\hline & 30.900 & $100 \times 100$ & 18,13 \\
\hline & 30.900 & $100 \times 100$ & 18,11 \\
\hline & & $100 \times 100$ & 17,37 \\
\hline
\end{tabular}

\subsection{Pengiriman Data Citra dengan Teknik Kompresi}

Pada pengujian data gambar yang terkompresi ini, digunakan metode Huffman untuk menyandikan gambar RGB dan mengubah format gambar ke JPEG. Setiap data RGB akan dikodekan menggunakan bantuan pohon biner huffman yang diterapkan dalam program android. Tabel 3 adalah tabel pengujian pengambilan gambar terkompresi dengan jarak yang sama dengan pengiriman gambar asli yang tidak terkompresi. Pengujian dilakukan pada Lab.PLC dengan beberapa objek berbeda. 
Tabel 3. Waktu pengiriman gambar RGB yang terkompresi

\begin{tabular}{|c|c|c|c|}
\hline Objek & $\begin{array}{c}\text { Ukuran } \\
\text { File (Byte) }\end{array}$ & Dimensi & $\begin{array}{c}\text { Waktu } \\
\text { (detik) }\end{array}$ \\
\hline & 2.960 & $100 \times 100$ & 5,67 \\
\hline & 3.160 & $100 \times 100$ & 5,53 \\
\hline & 3.050 & $100 \times 100$ & 5,48 \\
\hline & 3.370 & $100 \times 100$ & 5,64 \\
\hline & 2.450 & $100 \times 100$ & 5,67 \\
\hline & & $100 \times 100$ & 5,53 \\
\hline
\end{tabular}

Pada Tabel 3 menunjukkan hasil data gambar terkompresi yang dikirim oleh payload ke GCS. Ratarata waktu yang diperoleh untuk pengambilan gambar terkompresi adalah menghabiskan 5,55 detik lebih cepat daripada pengiriman data gambar yang tidak terkompresi.

\subsection{Perbandingan Ukuran Gambar}

Perbandingan ini dilakukan dengan melihat ukuran file yang secara otomatis tersimpan pada file komputer dari GCS. Untuk perhitungan rasio kompresi dilakukan dengan menggunakan rumus yang sudah dijelaskan pada bagian sebelumnya. Gambar 9 dan Gambar 10 menunjukkan perbandingan hasil dan ukuran gambar tanpa dan dengan teknik kompresi.

\section{1_Jul_Jam_18_24_50.bmp BMP File

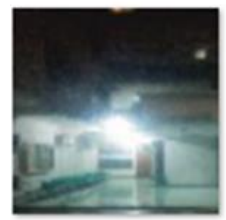

$$
\begin{array}{ll}
\text { Date modified: } & 7 / 11 / 20186: 24 \mathrm{PM} \\
\text { Dimensions: } & 100 \times 100 \\
\text { Size: } & 30.9 \mathrm{~KB} \\
\text { Date created: } & 7 / 13 / 201810: 13 \mathrm{AM}
\end{array}
$$

Gambar 9. Ukuran gambar yang tidak terkompresi

Ukuran gambar diatas, jika dihitung secara manual menggunakan rumus, akan diperoleh: $100 \mathrm{x}$ 100 Pixel, kedalaman warna 24 bit. Ukuran file asli yang akan diperoleh adalah: $100 \times 100 \times 24=240000$ bit $=240000 / 8$ Byte $=30000$ Byte atau 30 Kbyte .
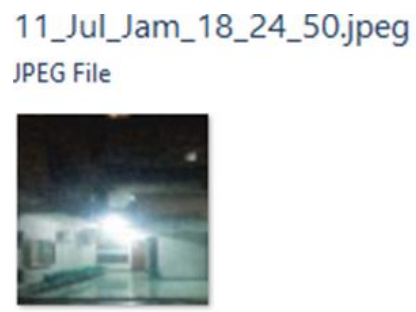

$\begin{array}{ll}\text { Date taken: } & \text { Specify date taken } \\ \text { Tags: } & \text { Add a tag } \\ \text { Rating: } & 100 \times 100 \\ \text { Dimensions: } & 1.42 \mathrm{~KB} \\ \text { Size: } & 2.45\end{array}$

Gambar 10. Ukuran citra yang terkompresi

Dari kedua gambar diatas dapat terlihat bahwa data gambar yang berukuran 30.9 KB berformat bitmap dan gambar JPEG ukuran 2.42 KB. Maka didapat rasio kompresi data gambar bitmap ke JPEG menghasilkan nilai $92.10 \%$.

\section{KESIMPULAN}

Dari hasil pengujian dan penelitian ini, dapat disimpulkan beberapa hal sebagai berikut.

1. Metode Huffman untuk proses kompresi gambar dapat diterapkan pada payload (muatan roket). Gitra terkompresi menggunakan metode Huffman menunjukan rata-rata waktu yang diperlukan untuk mengirim data gambar RGB yaitu sebesar 5,55 detik melalui radio 3DR lebih pendek diabandingkan dengan gambar yang 
berformat bitmap yang membutuhkan waktu 17.20 detik.

2. Transmisi data menggunakan modul radio 3DR dapat mencapai $600 \mathrm{~m}$ (tanpa halangan) di area terbuka. Tetapi sinyal radio akan melemah jika terjadi gangguan (noise) atau halangan.

\section{DAFTAR PUSTAKA}

[1] A. Widagdo, Implementasi Algoritma Metode Huffman Pada Kompresi Citra. Disertasi Doktor Fakultas Teknik. Universitas Muhammadiyah Surakarta. 2012.

[2] Howe, D., Free On-line Dictionary of Computing. (Online), diakses pada tanggal 22 April 2018, dari world wide web: http://www.foldoc.org/.

[3] I. F. Rahmad, dan H. Kurniawan, Kompresi File Citre Bitmap Menggunakan Algoritma RLE dan LZ78. Jurnal CSRID, 2011, pp. 81-92.

[4] T. R. Silviani, A. Arfiana, Teknik Kompresi Citra Menggunakan Metode Huffman. Seminar Nasional Matematika dan Pendidikan Matematika, 2016

[5] S. A. Sri, L. Suvi, R. S, Meningkatkan rasio kompresi citra digital dengan Huffman coding pada transfer data. Teknik Informatika. STMIK PPKIA Pradnya Paramita. Malang. 2014.

[6] A.A. Zulen, Penerapan Pohon Biner Huffman Pada Kompresi Citra. (Online), diakses pada tanggal 25 April 2018, dari world wide web: http:/ /informatika.stei.itb.ac.id/ rinaldi.munir /Matdis/20082009/Makalah2008/Makalah0809-077.pdf

[7] Linawati, H. P. Panggabean, Perbandingan kinerja algortima kompresi Huffman, LZW, dan DMC pada berbagai tipe file. Ilmu Komputer, FMIPA. Universitas Katolik Parahyangan. Bandung. 2004.

[8] Hendri, Kompresi Citra Dari Format BMP Ke Format PNG, Jurnal TIME, 2014, pp. 7-31.

[9] M. Rinaldi, Pengolahan Citra Digital dengan Pendekatan Algoritmik. Informatika, Bandung. 2004

[10]I. J. Sidabutar, Rancang Bangun Muatan Roket Berbasis Ponsel dan Penambahan Algoritma Permintaan Data Ulang Jika Terjadi Packet Loss. Laporan Penelitian. Fakultas Teknik dan Ilmu Komputer, 2016. 